\title{
PALEOCLIMATIC INTERACTIONS AND POPULATION DEVELOPMENT AT TACNA-PERU: THE ARCHAIC OF SOUTHERN PERU AND ITS UNKNOWNS
}

\section{Gary Martin Osorio Soto 1 0000-0002-9629-487X}

1 Programa de Maestría Universidad Europea del Atlantico1; martinosorio302@gmail.com

* Correspondence: martinosorio302@gmail.com; Tel.: +51-959-216-(Per)

\section{Abstract:}

The Environmental interactions contributed to the processes of settlement and development of the first settlers at southern Peru 15,000 BC. The determination of this process is based on paleoclimatic studies at southern Peru and ethnoarchaeological evidence. The determination of this process is based on paleoclimatic studies of southern Peru and ethnoarchaeological evidence; establishing as a result of this analysis the hypothesis of environmental interaction and territorial occupation of the first hunter-gatherer populations until their consolidation, dominating the geographical space from Tacna. The Disruptive disaster events and their effects on climate during the Peruvian Paleolithic resulted in the origin of local societies that shaped the Tiawanaku societies of the early horizon at Southern Peru and Northern Chile.

Keywords: Paleoclimatic variations in Southern Peru; Early human occupations in Tacna - Peru; Ethnoarchaeological analysis of the Populations in the Western Andes; Development of the Puquina

Culture in the Collisuyu territory.

\section{INTRODUCTION}

The development processes of human populations during the early stages on the Peruvian Archaic developed mainly due to the interrelation factors between the environment and the means of subsistence in the different ecological levels at Peruvian territory, as argued by (Bolaños 2010, 120-121). The diverse climatic interactions generated by cosmic events such as meteoric impacts during the late Pleistocene such as those of Wonderkrater $(12,800 \mathrm{BC})$ and Pilauco (12,718 BC), as pointed out by (Thackeray, Scott and Pieterse 2019, 31-32) and (Pino, M., Abarzúa, AM, Astorga, G. et al. 2019, 21) respectively, the same that promoted the glacial processes of the Younger Dryas, affecting the southern hemisphere and the populations that were found these populations, which also included populations in southern Peru and northern Chile. The geomorphological evidence from the coastal territories of southern Peru indicates that the Younger Dryas glacial generated the retraction of the oceanic beds, as well as the closure of the inter-Andean corridors that connected the coastline and the altiplano. The huntergatherer populations found in the coastal and inter-Andean environments changed their dynamics, as did the South American Holocene fauna, generating an overexploitation of species, leading to their extension, as in the case of giant sloths, bears such as Megatherium americanum, Glyptodon, Arctotherium angustidens, among others, 17.6Ka-9.8 Ka ago. Likewise, this process allowed the domestication of other species such as paleolamas (Hemiauchenia), among other species that served as sustenance for the populations from the southern Peruvian Paleolithic. The Paleolithic coastal populations of the southern coastal axis from Peru settled mainly at the mouths of the rivers that feed the headwaters of the Atacama Desert, interacting during the Younger Dryas glacial (12 ka-10. 8ka), the Andean interglacial (10ka) and the Lauricocha or Andean glaciation (9-8ka), as evidenced by the deposits of Quebrada Tacahuay, Quebrada Jahuay and El anillo, demonstrated that these populations during the climatic 
isolation developed fishing activities at Tacna coast 13-10 ka ago, as pointed out by (DeFrance and Alvarez 2004) and (Bolaños Baldasari 2007). In the area of the inter-Andean corridors, the sites of Toquepala, Qala Qala, Muruhuyo, Miculla [MalquLlai], Toquepala, show that some hunter-gatherer groups opted for the inter-Andean ecosystem floors where the populations of Andean deer and paleolamas provided sustenance, due to the weak climatic stability of these areas because of their geography. During the Andean interglacial period, coastal and altiplano components resumed commercial transfer processes, and with it also the transfer of flora and fauna species from Amazonian ecological levels, initiating a long process of domestication of these and initiating agricultural processes in an incipient form in the inter-Andean terraces; In the same way, the thaw caused the coastal desert paramos to be nourished with water resources from the thaw, generating the emergence of coastal hills (vegetation zones) where species such as Nolana andasonii (Solaneacea), Palaua dissecta (Malvacaea) Ephedra-sp (Ephedraceae) and Zephyranthes albicans and Helitropum arborensens began to populate these zones, allowing the development and demographic growth of endemic and migratory coastal fauna, serving as an additional resource to these coastal populations and allowing the control of their geographical environment with more sustainable resources, resulting in a process of consolidation and complex technification allowing their development towards complex societies that allowed their territorial, cultural and linguistic expansion as evidenced in the first phase of the Tiawanaku and Inca societies.

\section{MATERIALS AND METHODS}

The methods used for the development of this research were based on the comparative analysis of the documentary evidence of the various paleoclimatic, paleoarchaeological, archaeological, ethnolinguistic and anthropological studies developed by local and foreign authors at TacnaPeru region. Likewise, these data were corroborated by means of superficial prospection of the coastal and inter-Andean Paleolithic sites of the Region, carrying out a comparative stratigraphic analysis in the study areas. It should also be noted that, for the comparative analysis of the early horizon developments, documentary studies of chroniclers and expeditionaries were carried out, due to the fact that the geographic area is highly disturbed by natural and anthropogenic phenomena, so it was necessary to resort to first-hand documentary sources.

\section{RESULTS}

The research results indicate that there were 03 primary factors in the evolution of the populations of the Tacna territory in southern Peru, and they are: a) The environmental patterns of archaic southern Peruvian originated by the disaster events originated by meteoric impacts of Wonderkrater $(12,800 \mathrm{BC})$ and Pilauco $(12,718 \mathrm{BC})$, as pointed out by (Thackeray, Scott and Pieterse 2019, 31-32) and (Pino, M., Abarzúa, AM, Astorga, G. et al. 2019, 21) promoted harsh environmental patterns, the Younger Dryas glacial processes (12 ka-10. 8ka), the Andean interglacial (10ka) and the Lauricocha or Andean glaciation (9-8ka) promoted the contraction of populations in the inter-Andean valleys and coastal axes of Tacna; b) With the Andean Interglacial, Amazonian-Altiplano interactions were strengthened towards the coastal corridor of southern Peru and northern Chile, giving rise to the integration of trade patterns that allowed the domestication of species of fauna and flora in the coastal inter-Andean valleys, strengthening the processes of settlement and creation of local lordships in the coastal and Altiplano basins surrounding the Collao Plateau and Lake Titicaca; c) The climatic stability following the Andean microglacial (7ka) allowed the Collisuyo lordships to transform into Andean macro societies throughout the territory known as Collisuyo, giving rise to the Tiawanaku society. 


\section{Discussion}

\subsection{A perspective from the first settlements of southern Peruvian man.}

\{The gestation of the first settlements in southern Peru tends to have a diffuse contextualization; For some authors, such as (Lumbreras, 1974), (Posnansky, 1911), among others, point out that the settlement of southern Peru was a concatenation of migratory factors from Amazonian populations from the north to southern Peru to the coastal valleys, in contrast to the proposal made by the authors mentioned above, the studies of (Dillehay, 2013), (Uhle, 1919), (Heyerdahl, 1978) and (Stanford \& Bradley, 2013), who propose that the settlement of southern Peru is due to a demographic transfer of the first Clovis Solutrenses populations that arrived from the Atlantic through the Patagonian and Amazonian corridors prior to the climatic changes caused by meteoric impacts such as Wonderkrater and Pilauco, which later originated the isolation of these populations due to the Younger Dryas and Lauricocha glacial phenomena. The archaeological evidence found in the archaeological sites of Quebrada Tacahuay, El Anillo, Quebrada Jahuay, Qala Qala, Toquepala, among others, indicate that the populations in the western Andes adjacent to the Pacific Ocean basin in southern Peru were prior to these glacial processes, therefore, the dynamics of human mobilization during the Younger Dryas and Lauricocha were not affected by these glacial processes, the dynamics of human mobilization of the first South American and southern Peruvian inhabitants was due to migratory subsistence processes, having as a factor the fauna of large South American mammals that transited during the Great South American Biotic Exchange 21ka - 14ka ago, as pointed out by (Forasiepi, A. M., Soibelzon, L.H., et al. 2014, 973) and (Pelegrin, J.S., Gamboa, S., Menéndez, I., Hernández Fernández, M. 2018, 11-12). These biotic interactions between early American humans and migratory fauna led these groups to establish themselves directionally in the coastal and Amazonian-Cordilleran corridors within the South American territory, however, the isolation process caused by the Younger Dryas and Lauricocha glacial processes generated the encapsulation of these populations and the Paleoamerican megafauna, The demographic stress generated by the hunting processes of the first communities in the Western Andes corridor near the Pacific coast generated the extension of much of this megafauna and the domestication of some other minor species. With the "Andean Interglacial", the coastal-Amazonian highland corridors were reopened, generating a biotic micro-exchange, but this time generated by the human communities of these territories towards the coast. This interaction developed in a bidirectional manner, allowing the inter-Andean valleys to become hubs of trade and cultural exchange, as well as a natural laboratory for the domestication of Amazonian species such as the chili bell pepper (capsicum baccatum), beans (Phaseolus Vulgaris), pallar (Phaseolus Lunatus), Lucuma (Pouteria lúcuma), among others, as pointed out by (Shady 2003, 54-56). Likewise, this process of social integration generated by the factors of climatic stabilization allowed the confluence of cultural and demographic patterns of these human groups, as pointed out by the study of haplogroups and their DNA component of Andean populations generated by (Roothhammer and et al 2003, 273-274).

The processes of glacial expansion and contraction, especially with the Lauricocha process (1310.ka.) led to the isolation of coastal populations from the highlands. The "climatic calm" according to (Bolaños Baldasari, 2007, p. 43)-, promoted the resumption of migratory processes in the settled populations that began to dominate the geographical spaces of the Tacna territory, as evidenced by the early archaeological remains investigated by (Sandweiss, Daniel H.; McInnis, Heather; Burger, Richard L.; et al, 1998, p. 1832), (Ravines Sanchez, 1971, pp. 106-115), among others. The transition from hunter-gatherers to complex societies technologically adapted to 
the dominance of the ecosystemic environment led them to begin to forge their own semioticcultural codes that differentiated them from other human groups; however, due to commercial and social processes, they coupled some diverse elements within these territories. In the case of Tacna, there were two major periods that transformed the geographical environment, especially in the inter-Andean and coastal sectors. The climatic processes during the Andean Interglacial period led these hunter-gatherer groups to settle and forge a self-sustaining agriculture, which expanded into the inter-basin trade (from Arequipa to Tarapacá), allowing the coastal populations to have a significant population growth, leading them to expand their territorial domain. The first settlers came from the same nuclear social component throughout this territory, reflecting the cultural, semiotic and linguistic patterns among them, although with minimal differentiating agents, marked by the environment, as pointed out by (Sandweiss, Mclnnis, \& et al, 1998, pp. 1831-1832) and (Muñoz Ovalle, 2004, p. 215).

The bi-directionality brought as a consequence that the Altiplano-Amazonian groups transferred to the coastal territories intertwined with the local populations, generating social bridges between both totally different ecosystemic levels, as pointed out by (Sagarnága, 2007, p. 75), (Gordillo Begazo J., 1996, p. 97) and (Focacci Aste, 1981, pp. 66-67). This interaction was again stopped by the Andean micro glacial generated by the eruption of the Ubinas volcano (7840 b.C) generating environmental changes in the ecological floors of the south, as pointed out by (Juvigne, E. \& Thouret, J.C. \& Marino, et al. 2002, 338), this disruptive event generated a retraction of the inter-Andean developments of southern Peru, restarting and strengthening towards 5000 - 3600 years BC, as pointed out by (MASON J. A.., 1978 [1957], p. 313).

Around 3,200 to 600 B.C. during the Late Archaic and Early Formative periods, the human groups of Tacna had complex developments in pottery production, as pointed out by (Bolaños Baldasari, 2007, p. 199-203). 199-203), establishing from this productive pattern a sophistication of the societies in the coastal altiplanic axis of Tacna; As a result of this process of sophistication, actions of economic, social and cultural articulation were derived that integrated groups along the coastal corridor of Tacna and the inter-Andean axes to the north, south and east of the mountain range, the mutual integration of these local societies allowed the integration in a common identity semiological pattern, the same that would form the basis of the Tiawanaku society, as (Focacci Aste, 1981, pp. 66-63), adding that the author of the study, who was born in the Tiawanaku society (Focacci Aste, 1981, pp. 66-63), was the author of the study (Focacci Aste, 1981, pp. 66-63). 66-67), adding the author a stronger cultural root of pre-Tiawanaku groups.\}

\subsection{Components of climatic interaction and the first coastal populations of Tacna.}

\{The socio-demographic development in Tacna, as we have evidenced, has presented a series of stages, promoted mainly by climatological and environmental interactions within this geographical space, studies related to historical records of phenomena associated with ENSO in the southern coast of Peru and coastal regions has had components of significant climatic variation, the same that recorded peaks around the year 10,000/7,000/4000 BC as noted (Takahashi Guevara, Ken, 2016, p. 06).

For (Ayca Gallegos, 2006, p. 55), this process would have derived in the so-called "Tacana Culture", said culture -according to the author-, would have been developed from the integration of the groups of "Camanchacos" of the Tacna coast. The theorization of (Ayca Gallegos, 2006), does not correspond to an isolated cultural process, on the contrary, the pottery expression of the "Tacana Culture" would correspond to a much broader process at a spatial and temporal level that has been delimited by the bias of the researcher, therefore, the wrongly 
called "Tacana Culture", would be nothing more than the socio-cultural expression of a complex process of occupation and social and economic integration that would include the coastal populations from the southern coast of Arequipa to Tarapacá, which is evident in the cultural and semiological patterns left by these inhabitants of the Tacana territory. In the same sense (Reindel, Markus, \& Isla, Johny, 2013, pp. 85-88) establish the mechanisms of ecosystem interaction in the design and population development of these communities along the coastal and inter-Andean territory of the first populations of Tacna and southern Peruvian and northern Chilean. The archaeological sites of "El Cañón", "San Antonio", "Miculla", among others, are evidence of this.

The first architectural developments in the region respond to processes of use of materials for the development of permanent population settlements with capacity for territorial control and administrative-state development, the kingdoms in the southern corridor (Collisuyo) began to strengthen the local lordships towards a macro - state-imperial society, which translates into architectural and common patterns in these populations, a constant in the cultural maturation of these communities are the Chullpares developments, the same that began to spread towards 3. 500-1,600 BC as pointed out by (Romero Guevara, 2013, pp. 83-84), (Kesseli \& Pärssinen, 2005, p. 384); in such a way, that it cannot be ruled out that such architectural beginnings in the coastal-altiplanic corridor of Tacna are prior to the Tiawanacota development, as pointed out by (Szykulski, 2013/2014, p. 76) and (Romero G.., Santoro, \& al, 2004, p. 263) citing (Gordillo 1993). Archaeological records demonstrate integrated and adapted architectural patterns from the Early Horizon and Early-Intermediate Formative 1,200 BC and 600 AD such as evidence in the construction processes of huacas, as pointed out by (Belisario Gómez, 1861, p. 13), (Squier, 1877, pp. 241-243)] and (Smith (M.D.), 1864, p. 13). The German archaeologist Max Uhle (1919, p. 72) indicates that the modeling of the first complex architectural developments of Tacna were the huacas, which had a similar style to the constructions of Calasasaya, being the huacas and constructions of Tacna previous to the development of Calasasaya in the present territory of Bolivia.\}

\subsection{The Puquina origins of Tiawanaku societies}

The studies by (DeFrance and Alvarez 2004, 260-261), (Dillehay 2013, 17-18), (Bolaños Baldasari 2007, 348-349) and (Martinson and al 2003, 199-201) point out that the construction of the identity of the coastal settler of southern Peru developed over time due to the dynamics of social interaction within the spaces of climatic stabilization, According to (Muñoz and Chacama 2004, 218-219) the social and commercial articulation of the coastal populations of southern Peru and northern Chile with the altiplano would have promoted the development of commercial, cultural and social cohesions that gave rise to the first expressions of a regional macro consolidation, which would give rise to the Tiawanaku empire.

For (Bernedo Málaga 1947, 26-27) the bidirectional articulations brought as a consequence the first implementations of a macro-regional state-kingdom during the middle horizon (2000 1,100 years B.C.), generating components of social agglutination, around semiological and linguistic and cultural codes that gave origin to the Puquina culture. These developments took place in the diverse ecological levels of the territory between Arequipa and Copiapó, with incursions towards the altiplano as mentioned (Silva Sifuentes 2000, 215); this process of statecultural articulation would have begun 4.5-3.2 ka ago. Paleoarchaeological and archaeological studies indicate that the Andean paleo man, had complex cultural activities, these societies had complex cultural-ritualistic aspects, the same that would have decanted in linguistic codes with their own characteristics, the same that would make a difference with other bordering ethnic 
groups along the inter-Andean territory, as mentioned (Standen, Vivien G 2003, 179-180) and (Umire Alvarez 2013, 216-218). The socio-cultural patterns and their interactions, are reflected by (Bernedo Málaga 1947, 32-33) to define such integration as a macro-regional development culture.

The researcher Max Uhle (1919), in his archaeological work in Tacna and Arica, recognized components of early Tiawanaku phases in Tacna and Arica; the pottery patterns demonstrated an early Tiawanaku cultural presence in the coastal territories of southern Peru and northern Chile. Both Uhle and Bernedo Málaga - both citing Posnansky 1911 - refer to the Puquina as the socio-cultural axis of the first human components in the coastal territories of southern Peru, and their interrelation with the Altiplanic populations.

On the other hand (Kleeman, Otto; et al. 1975, 117-119) evidences a staggered process of implementation and consolidation of Tiawanaku Phase I patterns in the pottery remains of the Sama and Caplina Valleys, Tacna; this could induce to establish a context of bidirectionality of socio-cultural integration between the coastal and altiplanic lordships that shaped the Tiawanaku empire; in the same way $($ Uhle 1919, 09) delimits the influence of the Puquina Culture in this process of development of the populations in the coastal and inter-Andean corridors. Recent DNA studies made by (Rothhammer, F; et al 2014, 273-274), evidence that the predecessor groups of the Tiawanaku development, would not come from Aymara components. The gravitational axis of Tacna and Arica, in its socio-dynamic articulation between the coast and the altiplano to the Collao plateau, would have promoted the systematic interaction of altiplanic - coastal human components since 11 ka ago.

For (Posnansky 1913, 04-05) the origin of the Tiawanaku empire would have been based on the ethnic groups and local kingdoms surrounding the coast of the Pacific Ocean and the interAndean kingdoms between the coast and the Collao Plateau, which would confirm from the semiology, linguistic and archaeological the Tiawanaku genesis of Puquina elements of these areas, To this would contribute the research of (Bernedo Málaga 1947, 26-27), who points out that the integration of the local kingdoms from Arequipa to Atacama, would have engendered the linguistic, cultural and social codes of the Puquina, proof of this is the toponymic reflection that these areas still keep. However, authors such as (Baitzel and Rivera Infante 2019, 10) and (Vela Velarde 2019, 133-134); point out the presence of a cultural component called «Cabuza».

For these authors, the "Cabuzas", would be social components influenced by the Tiawanaku within the territories of Moquegua, the Sama Valley, Tacna and Arica around the tenth and eleventh century $A D$, the authors, fall into the interpretive regionalist phenomenon previously detailed, as was the established in the proposal of (Ayca Gallegos 2006, 55) with the "Tacana Culture", therefore, establishing ceramic styles with cultural agents is a very common conceptual problem in some researchers.

\section{CONCLUSIONS}

The works of (Bolaños Baldasari 2007), (DeFrance and Alvarez 2004), (Focacci Aste 1981), among others, indicate that the state development of the populations of Tacna began 13-10 ka ago; the influence of climatic conditions produced by natural disasters promoted processes of contraction and expansion of the societies from the Peruvian Southern Archaic. The processes of climatic stabilization contributed to human mobilizations along the altiplanic corridors surrounding the Collao Plateau, allowing the exchange of populations from the Coast and the Amazon, promoting the exchange of products from both geographic levels, promoting the 
development of agriculture through the domestication of species in more favorable ecological niches.

This process of social articulation led the groups of this coastal corridor (Moquegua - Tarapacá) to develop processes of social-cultural cohesion, which translated into architectural, pottery and cultural processes that gave identity to these early groups, as a result of this interaction there are processes of pottery and cultural similarity between the coastal kingdoms and Tiawanaku. The works (Bolaños Baldasari 2007) and (J. Gordillo Begazo 2014) allow us to demonstrate that these early social groups had ceramic patterns that precede Tiawanaku, therefore, assuming that Tiawanaku was nourished by the coastal social developments is a more than viable and substantial hypothesis.

The evidence of early settlements during the Early Archaic and the Middle Horizon in the coastal and inter-Andean valleys of Tacna suggests that these groups belonged to a single nucleus, which used different materials based on the availability of resources adjacent to their settlements, maintaining homogeneous patterns among them. Based on the patterns of social dynamics, which are maintained today, the inter-Andean corridors and the coastal-altiplano influence are a strong indication of this socio-cultural interrelationship, with which, the component of influence in the primary development of Tiawanaku, would come from a great influence of the coastal developments at southern Peru and northern Chile, the same that gave rise to the Puquina Culture, which was also the neural axis of the Tiawanaku empire at southern Peru.

Funding: Please add:This research dont receivedexternal funding

Acknowledgments: To my son and family who give me the strength to study and understand the historical and cultural heritage of Tacna, likewise to thank archaeologist Jesus Gordillo Begazo, who has allowed me to delve into the archaeological process at Tacna, being my best teacher.

Conflicts of Interest: The authors declare no conflict of interest.

\section{References}

Ayca Gallegos, Oscar Raúl. Historia Regional: Tacna prehispánica. Arequipa: Instituto de Estudios Andinos del Sur, 2006.

Belisario Gómez, José. El coloniaje. Tacna: Imp. de "El Porvenir" por J.H. Molina, 1861.

Bernedo Málaga, Leonidas. La cultura Puquina. Lima, Perú: Talleres e Imprenta del Ministerio de Educación del Perú, 1947.

Bolaños Baldasari, Aldo F. Tesis de grado: "El Cañon": un sitio del formativo temprano en el litoral de Tacna, Perú. Lima, Perú: Facultad de Ciencias Sociales - EAP de Arqueología UNMSM, 2007.

Bolaños, Aldo. «El reto vertical andino. Desafíos de la gravedad en las sociedades andinas precoloniales.» Arqueología y Sociedad, no 21 (2010): 119-130.

DeFrance, S., y A. Álvarez . "QUEBRADA TACAHUAY: UN SITIO MARÍTIMO DEL PLEISTOCENO TARDÍO EN LA COSTA SUR DEL PERÚ.» Chungara: Revista De Antropología Chilena 36, no 02 (2004): 257-278.

Dillehay, T.D. «Monte verde.» Encyclopedia of Earth Sciences Series, 2017: 538-539. 
Dillehay, Tom D. «Las Culturas del Pleistoceno Tardío en Suramérica.» Maguaré (Maguaré), no 17 (2013): 15-45.

Focacci Aste, Guillermo. «Nuevos fechados para la época Tiahuanaco en la arqueología del norte de Chile.» Chungará (Chungará) 08 (1981): 63-77.

Forasiepi, A.M., Soibelzon, L.H., et al. «Carnivorans at the Great American Biotic Interchange: new discoveries from the northern neotropics.» Die Naturwissenschaften 101, no 11 (2014): 965-974.

Frezier, Amadeo. Relación del Viaje por el Mar del Sur. 4ta edición. Paris: Editorial Ayacucho, 1716.

Gil García, Francisco M. «Acontecimientos y regularidades chullparias: más allá de las tipologías. Reflexiones entorno a la construcción del paisaje chullpario.» Revista Española de Antropología Americana, no 32 (2002): 207-241.

Gordillo Begazo, Jesús. «Desarrollo Regional Tardío y ocupación Inca en la pre-cordillera de Tacna.» Divulgación Ciencia \& Desarrollo, 1996: 96-111.

Guidon, Niéde. "Carbon-14 dates point to man in the Americas 32.000 years ago.» Nature, vol. $321, N^{\circ} 6072,1986: 769-771$.

Heyerdahl, Thor. Early Man and the Ocean: A Search for the Beginning of Navigation and Seaborn Civilizations. Londres, Inglaterra: Australian Institute for Maritime Archeology, 1978.

Juvigne, E. \& Thouret, J.C. \& Marino, et al. «Late Pleistocene and Holocene tephrostratigraphy and chronology in southern Peru.» Geodynamique andine, 2002: 335-338.

Kesseli, Risto, y Martti Pärssinen. «Identidad étnica y muerte: torres funerarias (chullpas) como símbolos de poder étnico en el altiplano boliviano de Pakasa (1250-1600 d. C.).» Bulletin de I'Institut français d'études andines 34, oo 03 (diciembre 2005): 379-410.

Kleeman, Otto; et al. Investigaciones arqueológicas en los valles del Caplina y Sama (Dep. Tacna, Perú). Vol. 25. Navarra: Verbo Divino, 1975.

Lumbreras, Luis Guillermo. Pueblos y Culturas del Antiguo Perú. Washington, Estados Unidos de Norteamérica: Smithsonian Institution Press, 1974.

Martinson, E., y et al. «Pathoecology of Chiribaya parasitism.» Mem Inst Oswaldo Cruz 98, no 01 (2003): 195-205.

MASON J. A. Las antiguas culturas del Perú. México D. F.: Fondo de Cultura Económica, 1978 [1957].

Muñoz Ovalle, Iván. «El Periodo Formativo en los valles del Norte de Chile y Sur de Perú: Nuevas evidencias y comentarios.» Chungará - Revista de Antropología Chilena. (Chungará) 36 (septiembre 2004): 213-225.

Muñoz, I., y J. Chacama. «EL PERÍODO FORMATIVO EN LOS VALLES DEL NORTE DE CHILE Y SUR DE PERÚ: NUEVAS EVIDENCIAS Y COMENTARIOS.» Chungará 36, no 01 (2004): 213225. 
Osorio Soto, Gary Martín. «INTERACCIONES PALEOCLIMÁTICA Y EL DESARROLLO POBLACIONAL DE TACNA-PERÚ: EL ARCAICO DEL SUR PERÚ Y SUS INCÓGNITAS.» MDPI, 2021: 01-06.

Pelegrin, J.S., Gamboa, S., Menéndez, I., Hernández Fernández, M. «El Gran Intercambio Biótico Americano: una revisión paleoambiental de evidencias aportadas por mamíferos y aves neotropicales.» Ecosistemas 27, no 01 (2018): 05-17.

Pino, M., Abarzúa, AM, Astorga, G. et al. «Sedimentary record from Patagonia, southern Chile supports cosmic-impact triggering of biomass burning, climate change, and megafaunal extinctions at 12.8 ka.» Scientific Report 9, no 4413 (marzo 2019): 1-27.

Posnansky, Arthur. El signo escalonado en las ideografías americanas con especial referencia á Tihuanacu. Berlín, Alemania: Editar Dietrich Reimer, 1913.

Posnansky, Arthur. Tihuanacu y la civilización prehistórica en el altiplano andino. La Paz: Imprenta de la Verdad, 1911.

Ravines Sánchez, Roger Hernán. «Tesis para el grado de Doctor en la especialidad de Antropología: Toquepala: estratigrafía y secuencia.» Vers. Online. Cybertesis UNMSM. Editado por Roger Hernán Ravines Sánchez. Universidad Nacional Mayor de San Marcos. 1971. https://hdl.handle.net/20.500.12672/9303 (último acceso: 13 de noviembre de 2021).

RB Firestone , A. West, JP Kennett, et al. «Evidencia de un impacto extraterrestre hace 12.900 años que contribuyó a las extinciones de megafauna y al enfriamiento del Younger Dryas." Actas de la Academia Nacional de Ciencias 104, oo 41 (octubre 2007): 1601616021.

Reindel, Markus, \& Isla, Johny. «CAMBIO CLIMÁTICO Y PATRONES DE ASENTAMIENTO EN LA VERTIENTE OCCIDENTAL DE LOS ANDES DEL SUR DEL PERÚ.» Dialogo Andino, no 41 (2013): 83-99.

Romero G., Álvaro, Calogero M. Santoro, y et al. «TÚMULOS, IDELOGÍA Y PAISAJE DE LA FASE ALTO RAMíREZ DEL VALLE DE AZAPA.» Chungara, Revista de Antropología Chilena 36, no 01 (2004): 261-272.

Romero Guevara, Alvaro. «CHULLPAS DE BARRO, INTERACCIÓN Y DINÁMICA POLÍTICA EN LA PRECORDILLERA DE ARICA DURANTE EL PERÍODO INTERMEDIO TARDÍO.» Textos Antropológicos 14, no 02 (2013): 83-104.

Roothhammer, F., y et al. «NÁLISIS DE ADNmt DE RESTOS ESQUELETALES DEL SITIO ARQUEOLÓGICO DE TIWANAKU Y SU RELACIÓN CON EL ORIGEN DE SUS CONSTRUCTORES.» Chungará (Arica) 35, no 02 (2003): 269-274.

Rothhammer, F; et al. «ANÁLISIS DE ADNmt DE RESTOS ESQUELETALES DEL SITIO ARQUEOLÓGICO DE TIWANAKU Y SU RELACIÓN CON EL ORIGEN DE SUS CONSTRUCTORES.»INTERCIENCIA 39, no 08 (2014): 586-590.

Sagarnága, Jédu. «Investigaciones arqueológicas en Pariti (Bolivia).» Editado por Ministerio de Educación Cultura y Deporte: Subdirección General de Documentación y Publicaciones. Anales del Museo de América N 15, ํo 15 (2007): 67-88.

Sagárnaga, Jédu, Korpisaari, y Antti. «Investigaciones Arqueologicas en Pariti (Bolivia).» En Andes: Boletín del Centro de Estudios Precolombinos de la Universidad de Varsovia $N^{\circ}$ 
07, de Janusz Z. Wołoszyn, Miłosz Giersz y Paweł Buda, 387- 410. Varsovia : I'Institut Français d'Études Andines, 2009.

Sandweiss, D., H. McInnis, y et al. «Quebrada Jaguay: Early South American Maritime Adaptations.» Science, 1998: 1830 -1832.

Sandweiss, Daniel H. ; McInnis, Heather; Burger, Richard L.; et al. «Quebrada Jaguay: Early South American Maritime Adaptations.» Sciense (Science) 281, no 5384 (1998): 18301832.

Santoro, Calogero , y Juan Chacama. «Secuencia de asentamientos precerámicos del extremo norte de Chile.» Estudios Atacameños № 7, 1984: 71-84.

Shady, Ruth. "La neolitización en los Andes Centrales y los La neolitización en los Andes Centrales y los La neolitización en los Andes Centrales y los orígenes del sedentarismo, la domesticación y orígenes del sedentarismo, la domesticación y la distinción social*.» En LA CIUDAD SAGRADA DE CARAL-SUPE civilización andina y la formación del LoS orígenes de la civilización andina y la formación del Estado prístino en el antiguo Perú, de Ruth Shady y Carlos Leyva, 37-50. Lima, Perú: Instituto Nacional de Cultura. Proyecto Especial Arqueológico Caral-Supe, 2003.

Silva Sifuentes, Jorge E.T. Origen de las Civilizaciones Andinas. Barcelona, España: Lexus, 2000.

Smith (M.D.), Archibald. Observaciones sobre las naciones Inca y Yunga, sus primeros restos; andon antiguos cráneos peruanos. Desde el Proc., Soc. de antiq. de Escocia. Edinburgo: Impreso en Neill and Company, 1864.

Squier, Ephraim George. Peru: Incidents of Travel and Exploration in the Land of the Incas. 1era. New York: Harper \& Brothers, Publishers, 1877.

Standen, V. G., y C. M. Santoro. «Patrón funerario arcaico temprano del sitio Acha-3 y su relación con Chinchorro: Cazadores, pescadores y recolectores de la costa norte de Chile. .» Latin American Antiquity Vol.15. N¹, 2004: 89-109.

Standen, Vivien G. «BIENES FUNERARIOS DEL CEMENTERIO CHINCHORRO MORRO 1: DESCRIPCIÓN, ANÁLISIS E INTERPRETACIÓN.»Chungará 35, no 02 (2003): 175-207.

Stanford, D., y B. Bradley. Across Atlantic Ice: The Origin of America's Clovis Culture. California, Estados Unidos de Norteamérica: University of California Press, 2013.

Szykulski, Józef . «La Época Precerámica en la zona arqueológica de Churajón, sur del Perú.» Estudios Latinoamericanos, ํo 34 (2013-2014): 75-96.

Szykulski, Józef. «La Época Precerámica en la zona arqueológica de Churajón, sur del Perú.» Revista de la Sociedad Polaca de Estudios Latinoamericanos (Polskie Towarzystwo Studiów Latynoamerykanistycznych) 33/34 (2013/2014): 75-96.

Takahashi Guevara, Ken. «Variabilidad del ENSO durante el Holoceno: evidencias paleoclimáticas.» "Generación de información y monitoreo del Fenómeno El Niño" (Instituto Geofísico del Perú) 03, no 02 (febrero 2016): 05-08.

Teller, J., Boyd, M., LeCompte, M., Kennett, et al. «A multi-proxy study of changing environmental conditions in a Younger Dryas sequence in southwestern Manitoba, 
Canada, and evidence for an extraterrestrial event.» Quaternary Research, no 93 (2020): 60-87.

Thackeray, J., L. Scott, y P. Pieterse. «El intervalo Younger Dryas en Wonderkrater (Sudáfrica) en el contexto de una anomalía del platino.» Palaeontologia africana, 2019: 30-35.

Truc, Loïc, M. Chevalier, y et al. " Quantification of climate change for the last 20,000 years from Wonderkrater, South Africa: implications for the long-term dynamics of the Intertropical Convergence Zone.» Palaeogeography, Palaeoclimatology, Palaeoecolog, 2013: 575-587.

Uhle, Max. La arqueología de Arica y Tacna. Quito, Ecuador: Imprenta de la Universidad Central, 1919.

Umire Álvarez, Adán. «RASGOS FUNERARIOS CHINCHORRO EN LA COSTA DEL EXTREMO SUR PERUANO.» Chungará (Arica), Vol. 45 N². 45, no 02 (2013): 209-235.

Vela Velarde, Carlos. «Bases para el conocimiento de la presencia Tiawanaku en el Valle del Caplina, Tacna.» Ciencia \& Desarrollo (Universidad Nacional Jorge Basadre Grohmann), no 4 (2019): 125-137.

Velarde , Leonid. «Problemática de los fechados Carbono 14 y su calibración: El caso del formativo de los andes centrales.» Arqueología y Sociedad, no 12 (1998): 11-28. 